\section{UJMM

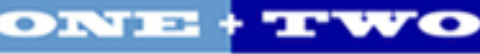

Volume 2 | 2010 Spring

\section{Undergraduate Journal of Mathematical}

Modeling: One + Two

2010

\title{
Pasteurization of Milk
}

Alejandro Barbosa Alzate

University of South Florida

Advisors:

Masahiko Saito, Mathematics and Statistics

Scott Campbell, Chemical \& Biomedical Engineering

Problem Suggested By: Scott Campbell

Follow this and additional works at: https://digitalcommons.usf.edu/ujmm

Part of the Mathematics Commons

UJMM is an open access journal, free to authors and readers, and relies on your support:

Donate Now

\section{Recommended Citation}

Barbosa Alzate, Alejandro (2010) "Pasteurization of Milk," Undergraduate Journal of Mathematical

Modeling: One + Two: Vol. 2: Iss. 2, Article 1.

DOI: http://dx.doi.org/10.5038/2326-3652.2.2.1

Available at: https://digitalcommons.usf.edu/ujmm/vol2/iss2/1 


\title{
Pasteurization of Milk
}

\begin{abstract}
We determined the time it takes milk, which is heated from $60^{\circ} \mathrm{F}$ to $150^{\circ} \mathrm{F}$, to achieve pasteurization and compared this result with the standard pasteurization process of heating milk at a constant temperature of $150^{\circ} \mathrm{F}$ for 30 minutes. Instead of directly quantifying the bacterium population, we considered the bacteria to milk concentration ratio. To solve for the unknown time, we equated the final bacterium concentration ratio achieved through both varied temperature and constant temperature. After equating the final pasteurization concentrations we were unable to find an analytical solution, so we used numerical techniques to find the unknown heating time.
\end{abstract}

\section{Keywords}

Pasteurization, Temperature Changes, Decimal reduction time

\section{Creative Commons License}

(c) (i) (अ)

This work is licensed under a Creative Commons Attribution-Noncommercial-Share Alike 4.0 License. 


\section{TABLE OF CONTENTS}

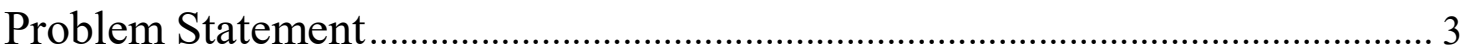

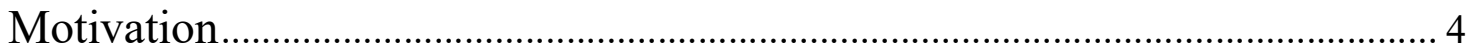

Mathematical Description and Solution Approach ......................................... 5

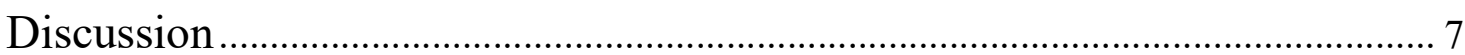

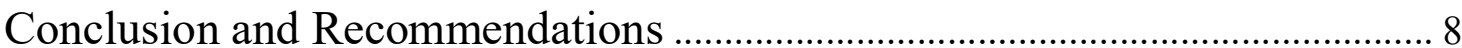

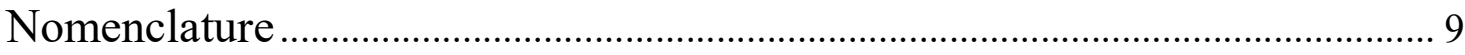

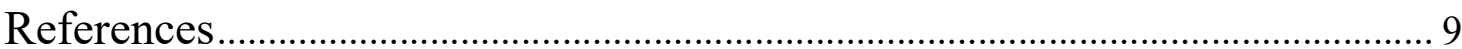

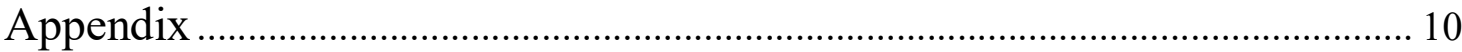




\section{PROBLEM STATEMENT}

Bacteria in milk are destroyed through a process called pasteurization, which is mild heating over a specific period of time. The amount of time required to destroy a certain amount of bacteria depends on the temperature. In pasteurization the number of bacteria, $N$, decays with time according to the formula

$$
\frac{d N}{d t}=\frac{-2.303}{D_{T}} N
$$

where $D_{T}$, known as the decimal reduction time, is the time required to kill $90 \%$ of microorganisms at a constant temperature $T$. Values of $D$ are generally scaled to a reference temperature of $150^{\circ} \mathrm{F}$ according to the following relationship:

$$
D_{T}=D_{150}\left(10^{\frac{150-T}{z}}\right)
$$

where $D_{T}$ is the $D$ value at temperature $T$ (in ${ }^{\circ} \mathrm{F}$ ), $D_{150}$ is the $D$ value at $150^{\circ} \mathrm{F}$, and $z$ is the thermal death time. The thermal death time is the change in $D_{T}$ associated with the change in $T$. For pasteurization of milk, the quantity $z$ has a value of 9.0 and $D_{150}$ may be taken to be 2.0 minutes.

Milk may be considered pasteurized if it is held at $150^{\circ} \mathrm{F}$ for 30 minutes. However, in a process that a company uses, the milk starts out at $60^{\circ} \mathrm{F}$ and is heated over time. The temperature of the milk varies with time according to:

$$
\frac{d T}{d t}=-0.2(T-150)
$$

with the initial temperature $T(0)=60$.

Determine the number of minutes that the milk should be heated to achieve the same bacteria level as it would if it was heated at a constant temperature of $150^{\circ} \mathrm{F}$ for 30 minutes. 


\section{MOTIVATION}

In many real world situations, there are different companies that use different processes to accomplish the same task. Here for instance, we compared the constant temperature pasteurization process used by one company to the changing temperature pasteurization process used by another company. Both companies may have the same goal in mind, but they used different methods.

It is important to notice that pasteurization is not intended to destroy all pathogenic microorganisms in food or liquid. Rather, pasteurization aims to reduce the number of viable pathogens so that they are unlikely to cause disease. Therefore, both companies had to ensure that bacteria concentrations were reduced to a safe level.

Engineers use science to resolve these types of problems. In the case of pasteurization, constant heating is known to be effective, but other procedures may be explored for use in cases of physical limitations or simply to increase productivity. It is helpful to have several techniques for reaching the same goal, which in this case are safe bacteria concentrations in milk. More generally, the objective of this project was to apply the concepts of calculus to such real world situations. 


\section{MATHEMATICAL DESCRIPTION AND SOLUTION APPROACH}

We begin by calculating the bacteria concentration which remains after heating milk for 30 minutes at a temperature of $150^{\circ} \mathrm{F}$. From the problem statement, we know that the number of bacteria $N_{t}$ decays with time $t$ according to the equation

$$
\frac{d N}{d t}=\frac{-2.303}{D_{T_{t}}} N_{t}
$$

In this case, temperature is fixed at $T_{t}=150$ and is $D_{150}=2$. Thus, $\frac{d N}{d t}=-1.1515$ which implies that $\frac{d N_{t}}{N_{t}}=-1.1515 d t$. Since $N_{t}$ is a function of time in this system, when we integrate both sides of this equation we get

$$
\int \frac{d N_{t}}{N_{t}}=\int-1.1515 d t
$$

which evaluates to

$$
\ln \left(N_{t}\right)=-1.1515 t+c
$$

i.e.

$$
N_{t}=c e^{-1.1515 t}
$$

for some constant $c$. We see that at time $t=0$ the above equation becomes $c=N_{0}$, so we can express the solution as

$$
N_{t}=N_{0} e^{-1.1515 t}
$$

In this process, the final concentration occurs at time $t=30$, so we see that the natural logarithm of the final to initial concentration ratio is a fixed number. In particular,

$$
\ln \frac{N_{t}}{N_{0}}=-1.1515 \times 30=-34.545 \text {. }
$$


Now we are ready to consider the case where the milk temperature starts at $60^{\circ} \mathrm{F}$ and increases to $150^{\circ} \mathrm{F}$ according to the formula

$$
\frac{d T_{t}}{d t}=-0.2\left(T_{t}-150\right)
$$

Before we can consider the bacteria concentrations, we must first solve (4) in a similar fashion to solving (1). In fact, (4) is solved in the following manner:

$$
\frac{d T_{t}}{\left(T_{t}-150\right)}=-0.2 d t \quad \Longrightarrow \quad \int \frac{d T_{t}}{T_{t}-150}=-0.2 \int d t \quad \Longrightarrow \ln \left(T_{t}-150\right)=-0.2 t+c
$$

which simplifies to

$$
T_{t}=150+c e^{-0.2 t}
$$

When $t=0$, we are at the starting temperature $T_{0}=60^{\circ} \mathrm{F}$. Thus, we may solve for $c=-90$ and we have a solution for (4) being

$$
T_{t}=150-90 e^{-0.2 t}
$$

Unlike the previous case, the value of $D_{T}$ varies over time as the temperature changes. In particular,

$$
D_{T_{t}}=D_{150} 10^{\frac{150-T_{t}}{z}}
$$

For the pasteurization of milk, we know $z$ to be around 9 (P. Michael Davidson, 2003). Using $D_{150}=2$ as we did before and (5), equation (6) becomes

$$
D_{T_{t}}=2 \cdot 10^{\frac{150-\left(150-90 e^{-0.2 t}\right)}{9}}=2 \cdot 10^{10 e^{-0.2 t}} .
$$

Now that we have the function for $D_{T_{t}}$, we can plug in equation (7) into equation (1) and solve for the ratio of bacteria concentration:

$$
\frac{d N_{t}}{d t}=\frac{-2.303}{2 \cdot 10^{10} e^{-0.2 t}} N_{t} \quad \Longrightarrow \quad \int_{N_{0}}^{N_{t}} \frac{d N_{t}}{N_{t}}=\int_{0}^{t} \frac{-1.1515}{1010 e^{-0.2(t)}} d t
$$


which implies

$$
\ln \left(N_{f}\right)-\ln \left(N_{i}\right)=\ln \left(\frac{N_{f}}{N_{i}}\right)=\int_{0}^{t} \frac{-1.1515}{10^{10} e^{-0.2(t)}} d t
$$

Finally, we use the fact that we started with the same initial bacteria concentration $N_{0}$ as in the fixed temperature case and wish to stop the heating when the concentration reaches the final concentration from the first case $N_{f}$. This is a fixed number which we solved for in (3).

Substituting (3) into equation (8) we get:

$$
-34.545=\ln \left(\frac{N_{f}}{N_{i}}\right)=\int_{0}^{t} \frac{-1.1515}{10^{10} e^{-0.2(t)}} d t
$$

Equation (9) informs us that there exists a value of $t$ in which will yield -34.545 . Since this integral cannot be found analytically, we have to use numerical techniques. Excel gave the approximate solution of $t=48.54$ minutes.

\section{DISCUSSION}

The time it took to the variable heating process to reach pasteurization concentrations was 48.54 minutes ( 48 minutes, 32 seconds). This means that the variable temperature process for the pasteurization of milk used by the second company will take about 18 minutes longer than if they had used the constant temperature of $150^{\circ} \mathrm{F}$ for 30 minutes. This result is intuitive because the second pasteurization starts with a lower temperature and it gets hotter over time but with a limit of $150^{\circ} \mathrm{F}$. The bacteria die at a slower rate under the colder temperatures.

This implies that the first company can process more and faster milk than the second company. The second company will require $62 \%$ more time to process the same amount of milk. Note that equation (9) is unique to this particular temperature scheme. If the second plant decides to start at a different temperature or change the rate in which the temperature varies with time, it will be necessary to solve for a new $D_{T_{t}}$. 


\section{CONCLUSION AND RECOMMENDATIONS}

Starting the pasteurization process from a lower temperature and slowly increasing it to full heat takes longer to kill bacteria that starting at full heat. In this particular problem, it was found that it will require about 18 more minutes for the variable heating than the constant temperature. Normally, at a constant temperature of $150^{\circ} \mathrm{F}$, it is necessary to heat milk for 30 minutes to reach safe bacteria levels. If the milk is initially heated at $60^{\circ} \mathrm{F}$ before being increased to $150^{\circ} \mathrm{F}$ it takes 48.56 minutes to achieve the same results.

It is recommended that future studies explore variations on higher and lower temperatures to determine which method is most effective. 


\section{NOMENCLATURE}

$\begin{array}{cll}\text { Symbol } & \text { Meaning } & \text { Units } \\ \boldsymbol{D}_{T_{t}} & \text { Decimal reduction time at temperature } T_{t} & \text { Minutes }(\mathrm{min}) \\ \boldsymbol{N}_{\boldsymbol{t}} & \text { Number of Bacteria at time } t & \text { Bacterium } \\ t & \text { Time } & \text { Minutes }(\mathrm{min}) \\ \boldsymbol{T}_{\boldsymbol{t}} & \text { Temperature at time } t & \text { Degrees Fahrenheit }\left({ }^{\circ} \mathrm{F}\right) \\ \boldsymbol{z} & \text { Thermal Death Time (also TDT) } & \text { Minutes }(\mathrm{min})\end{array}$

\section{REFERENCES}

P. Michael Davidson, J. W. (2003). Decimal Reduction Times. In D. R. Heldman, Encyclopedia of agricultural, food, and biological engineering (pp. 165-171). New York: Marcel Dekker, Inc.

Dr. Scott Campbell - Helped with the numerical methods and offered the idea of choosing a ratio of concentrations. 


\section{APPENDIX}
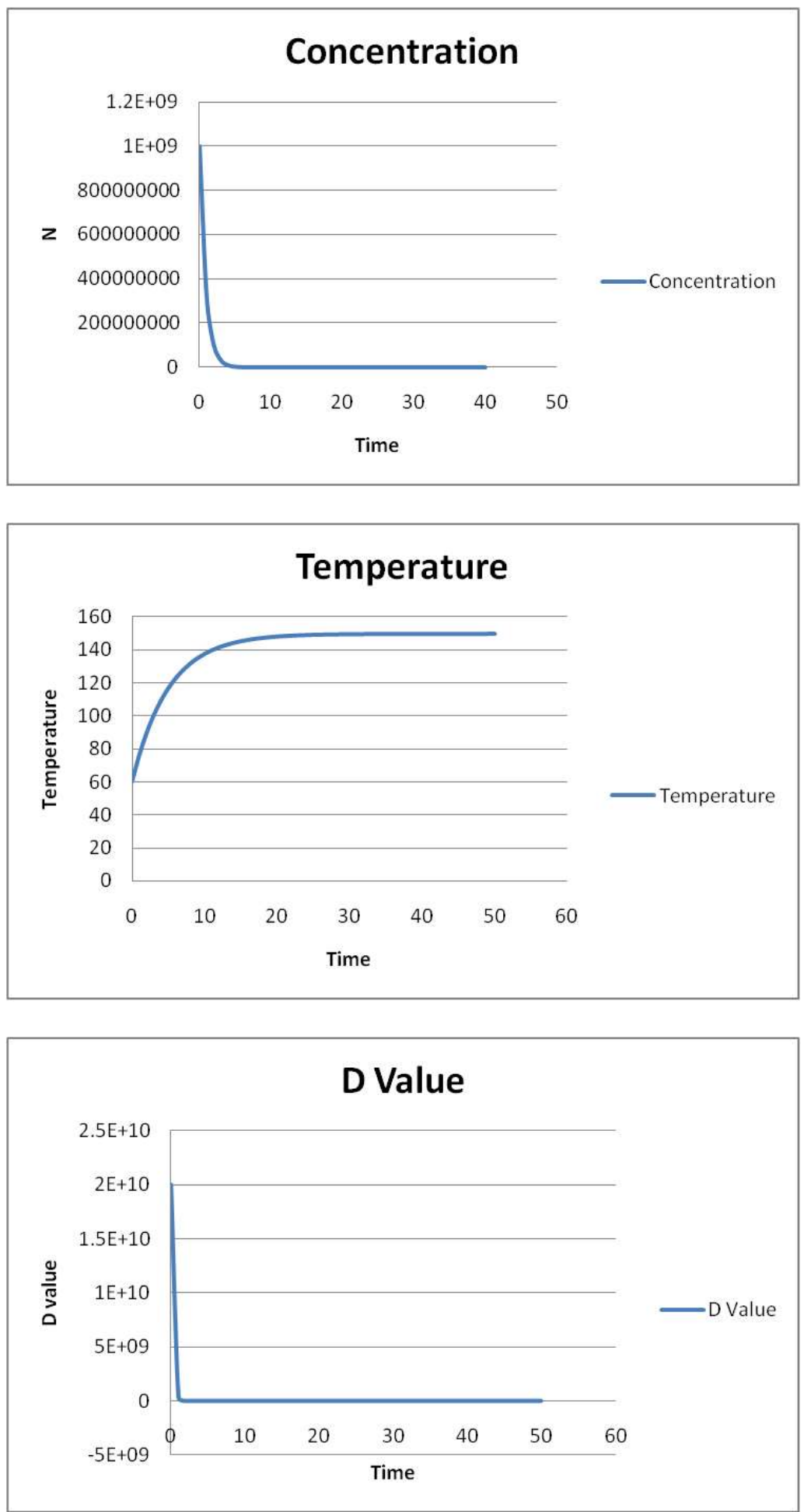